Aleksandra Partyk

Krakowska Akademia im. Andrzeja Frycza Modrzewskiego

\title{
Powodowanie rozkładu pożycia rodzinnego jako podstawa zobowiązania do podjęcia leczenia odwykowego przeciwalkoholowego - w świetle orzecznictwa sądowego
}

\section{Causing the Breakdown of Family Life as Liability to Take Part in Withdrawal Treatment - In Light of Judicial Practice}

\begin{abstract}
Abstrakt
W przepisach ustawy z dnia 26 października 1982 r. o wychowaniu w trzeźwości i przeciwdziałaniu alkoholizmowi przewidziano możliwość zastosowania obowiązku leczenia odwykowego przeciwalkoholowego względem osoby uzależnionej. Przymusowe leczenie odwykowe może być prowadzone w systemie niestacjonarnym lub stacjonarnym. Obie formy leczenia odwykowego stanowią jednak ustawowy wyjątek, bowiem jako zasadę przewidziano dobrowolne podejmowanie leczenia nałogu. W judykaturze wskazuje się w szczególności, że samo uzależnienie od alkoholu nie wystarcza do zobowiązania uczestnika do podjęcia leczenia odwykowego przeciwalkoholowego. Musi istnieć również tzw. przesłanka społeczna. Jedną z nich jest powodowanie przez osobę uzależnioną rozkładu życia rodzinnego. W praktyce orzeczniczej sądów odwoływanie się do tej okoliczności występuje często. Jednakże ustalenie, czy ma ona faktycznie miejsce, ma charakter ocenny. Nie każdy bowiem konflikt w rodzinie jest tożsamy z rozkładem pożycia. Poza tym nie można uwzględnić wniosku, jeżeli doszło już do definitywnego rozpadu więzi rodzinnych. Sąd uwzględnia przy tym stan istniejący w dacie zamknięcia rozprawy, a zatem poprawa postępowania osoby uzależnionej, w tym podjęcie dobrowolnej terapii, musi wpływać na ostateczny kierunek rozstrzygnięcia sądu. Orzekanie o zobowiązaniu do podjęcia leczenia odwykowego przeciwalkoholowego jest szczególnie istotne, jeżeli zachodzi realna obawa, że kryzys rodziny dotkniętej alkoholizmem jednego z jej członków będzie się pogłębiał. Szybkość reakcji aparatu państwowego zwiększa zarazem prawdopodobieństwo sukcesu.
\end{abstract}

Słowa kluczowe: rodzina, uzależnienie, alkoholizm, leczenie odwykowe

\section{Wprowadzenie}

W preambule ustawy z dnia 26 października 1982 r. o wychowaniu w trzeźwości i przeciwdziałaniu alkoholizmowi (tekst jedn. Dz.U. z 2018 r., poz. 2137, dalej jako „ustawa”) przyjęto, że niezbędnym warunkiem moralnego i materialnego dobra narodu jest życie obywateli w trzeźwości. Jednym z kluczowych uregulowań tej ustawy jest możliwość wydania przez sąd orzeczenia o zobowiązaniu osoby uzależnionej do podjęcia leczenia odwykowego przeciwalkoholowego, pod warunkiem zaistnienia ustawowo przewidzianych przesłanek. Istnienie sądowego trybu 
zobowiązywania do leczenia odwykowego przeciwalkoholowego nie oznacza jednak, że ustawodawca stworzył tryb leczenia „pod przymusem”. W obecnym stanie prawnym nie ma podstawy normatywnej do przymusowego poddania osoby uzależnionej od alkoholu leczeniu odwykowemu. Sąd, uznając wniosek za zasadny, orzeka o zobowiązaniu osoby uzależnionej do poddania się leczeniu i wskazuje stacjonarny lub niestacjonarny system lecznictwa odwykowego, w którym taka terapia ma być prowadzona. Nie ma jednak mowy o „zmuszeniu” uczestnika postępowania do leczenia - osoba uzależniona, co do której zostanie uwzględniony wniosek, może odmówić podjęcia terapii odwykowej (Fiutak, 2016, LEX/el).

Orzeczenie sądu zobowiązujące do poddania się leczeniu nie zastępuje zgody osoby uzależnionej na leczenie. Przez cały czas trwania sądowego obowiązku leczenia sąd stosuje przewidziany prawem przymus doprowadzania do zakładu leczenia, jeśli jednak osoba uzależniona nie wyrazi zgody na kurację, postanowienie sądu nie zostanie wykonane (Horna-Cieślak, 2017, s. 3).

Bez względu na powyższe, leczenie odwykowe, do którego podjęcia sąd może zobowiązać osobę uzależnioną, należy traktować jako wyjątek. Jako zasadę przewidziano dobrowolne podejmowanie leczenia nałogu, zgodnie $z$ art. 21 ustawy (Partyk, 2014, C2). Podkreślenia wymaga, że sąd może orzec o zobowiązaniu uczestnika do podjęcia leczenia odwykowego, a nie orzeka o przymusowym leczeniu. Ten zabieg językowy jest nieprzypadkowy; wiąże się z odejściem przez prawodawcę od zasady, że osoba nadużywająca alkoholu może być do leczenia zmuszona (Horna-Cieślak, 2017, s. 8). Na prymat dobrowolności leczenia względem przymusu zwrócił uwagę Trybunał Konstytucyjny w wyroku z dnia 4 lipca 2006 r. w sprawie K 43/05 (LEX nr 198667). Trybunał zauważył, że odmowy podjęcia terapii przez osobę uzależnioną nie można postrzegać jako zachowania bezprawnego. Sąd konstytucyjny wyjaśnił, że

osoba uzależniona ma prawo do wolności osobistej i ochrony godności. Sposób życia osoby odmawiającej leczenia odwykowego wymaga interwencji władzy publicznej z innych powodów, które ustawa antyalkoholowa traktuje jako przesłanki wystąpienia [...] do sądu, mającego orzec o ograniczeniu praw tej osoby ze względu na bezpieczeństwo i porządek publiczny oraz prawa i wolności innych osób.

Przytoczony fragment w dobitny sposób unaocznia istnienie przeciwstawnych wartości. Z jednej strony funkcjonuje prawo (wolność) osoby, która jest uzależniona od alkoholu do odmowy poddania się leczeniu. Z drugiej - państwo ma stać na straży praw i wolności innych osób krzywdzonych z powodu cudzego nałogu alkoholowego. Chodzi tu przede wszystkim o członków rodziny osoby uzależnionej i osób z jego otoczenia. Rodzina zaś podlega szczególnej ochronie, co wynika z art. 18 Konstytucji. Rolą państwa jest również zapewnianie bezpieczeństwa i porządku publicznego. Tymczasem osoby uzależnione od alkoholu niejednokrotnie godzą w ład społeczny, dopuszczając się zachowań agresywnych czy niebezpiecznych dla innych osób. Aby wyważyć istnienie tych przeciwstawnych wartości, ustawodawca wprowadził w ustawie zamknięty katalog przesłanek, które uzasadniają orzeczenie przez sąd o zobowiązaniu uczestnika do poddania się leczeniu odwykowemu. W świetle art. 24 w zw. z art. 26 ust. 1 ustawy osoby, które w związku z nadużywaniem alkoholu powodują rozkład życia 
rodzinnego, demoralizację małoletnich, uchylają się od obowiązku zaspokajania potrzeb rodziny albo systematycznie zakłócają spokój lub porządek publiczny, mogą zostać sądownie zobowiązane do poddania się leczeniu w stacjonarnym lub niestacjonarnym zakładzie lecznictwa odwykowego - jeśli są uzależnione od alkoholu. Do sądowego zobowiązania uczestnika postępowania sądowego nie dojdzie, jeśli nie jest on uzależniony od alkoholu. Sąd również nie może de lege lata uwzględnić złożonego wniosku, jeśli mimo uzależnienia uczestnika od alkoholu nie istnieją negatywne zjawiska społeczne. Oprócz przesłanki medycznej (choroby alkoholowej stwierdzonej w oparciu o opinię biegłych specjalistów) wystąpić musi bowiem przynajmniej jedna z tzw. przesłanek społecznych, która wiąże się z krzywdzeniem innych osób (Grotkowska, 2018, s. 88). Przyjmuje się jednolicie, że przesłanki medyczne i społeczne mają wystąpić łącznie, by móc uwzględnić złożony wniosek (Partyk, 2014, LEX/el). Sąd Najwyższy w uzasadnieniu uchwały z dnia 26 marca 1986 r., III CZP 72/85 (LEX nr 3203) wyjaśnił, że uwzględnienie wniosku jest możliwe jedynie względem osób uzależnionych, „których postępowanie rażąco godziło właśnie w te wartości życia społecznego i w zasadzie miało znamiona deliktu, a niekiedy przestępstwa zagrożonego karą pozbawienia wolności".

Czy jednak w każdym wypadku, gdy osoba uzależniona dopuszcza się negatywnych zachowań w związku z uzależnieniem alkoholowym, sądy uwzględniają wnioski prokuratury i gminnych komisji rozwiązywania problemów alkoholowych? W praktyce orzeczniczej zauważalna jest tendencja, by przepisy ustawy o wychowaniu w trzeźwości i przeciwdziałaniu alkoholizmowi poddawane były wykładni ścisłej. Jest to związane z podstawowym założeniem, że zobowiązanie do poddania się leczeniu odwykowemu stanowi ingerencję w konstytucyjną wolność osoby, w związku z czym jest dopuszczalne jedynie w przypadkach niebudzących wątpliwości. To praktycznie doniosłe zagadnienie chciałabym przedstawić w odniesieniu do jednej z przesłanek społecznych: powodowania przez uczestnika rozkładu życia rodzinnego w związku z nadużywaniem alkoholu. Analiza orzecznictwa sądowego zwraca uwagę na mocne i słabe punkty przyjętych przez prawodawcę rozwiązań normatywnych. Kluczowe bowiem dla funkcjonowania norm prawnych jest to, w jaki sposób są one stosowane w praktyce orzeczniczej sądów.

\section{Zarys procedury przed sądem}

Sądem, który bada wnioski o leczenie odwykowe, jest w pierwszej instancji sąd rejonowy, zaś apelacje od zapadłych orzeczeń rozpoznają sądy okręgowe. Po uprawomocnieniu się orzeczenia w sprawie może zostać złożona skarga kasacyjna do Sądu Najwyższego (zob. postanowienie Sądu Najwyższego z dnia 19 grudnia 2001 r., IV CZ 207/01, LEX nr 52756). Jeśli sąd uzna, że wniosek nie jest zasadny, podlegać on będzie oddaleniu. Jeśli natomiast w przekonaniu sądu zaistnieją podstawy do uwzględnienia wniosku, to sąd orzeknie o zobowiązaniu uczestnika do poddania się leczeniu odwykowemu przeciwalkoholowemu w stacjonarnym bądź niestacjonarnym zakładzie lecznictwa odwykowego (art. 26 ust. 1 
ustawy). Sąd może przy tym nałożyć na uczestnika nadzór kuratora sądowego (art. 31 ustawy). Sądy, orzekając na podstawie przepisów ustawy o wychowaniu w trzeźwości i przeciwdziałania alkoholizmowi, rozpoznają sprawy w postępowaniu nieprocesowym, w którym merytoryczne orzeczenie kończące postępowanie w danej instancji przybiera formę postanowienia (a nie wyroku). W razie uprawomocnienia się postanowienia o zobowiązania uczestnika do leczenia odwykowego sądy rejonowe prowadzą nadzór nad wykonywaniem orzeczenia (Partyk, 2014, LEX/el). W postępowaniu wykonawczym sąd czuwa nad procesem leczenia odwykowego uczestnika i może podejmować stosowne decyzje procesowe zmierzające do realizacji orzeczenia (Horna-Cieślak, 2017, s. 18).

De lege lata podmiotami uprawnionymi do zainicjowania sądowej procedury są wyłącznie prokurator oraz gminna komisja rozwiązywania problemów alkoholowych (art. 26 ust. 3 ustawy). Ten wąski krąg uprawnionych związany jest z potrzebą nadzorowania wszczynanych postępowań o zastosowanie leczenia odwykowego. Wyłączenie innych podmiotów z możliwości złożenia wniosku wyklucza zatem dopuszczalność prawną składania wniosków „prywatnych” przez inne osoby i podmioty. Jak słusznie wyjaśnił Trybunał Konstytucyjny w przywołanym już wcześniej wyroku w sprawie K 43/05, takie rozwiązanie wynika z potrzeby unikania sytuacji, które pogłębią konflikty w rodzinie, co doprowadzić może do skutków sprzecznych z celami przyjętej ustawy. Z pewnością dzięki temu zabiegowi legislacyjnemu wyklucza się inicjowanie postępowań w przedmiocie zobowiązania osoby do poddania się leczeniu przeciwalkoholowemu w złej wierze. Oczywistym jest bowiem, że bezzasadnie inicjowane postępowania sądowe, zwłaszcza gdyby czyniły to osoby skonfliktowane z uczestnikiem, mogłyby wpływać na jego stygmatyzację w danej społeczności i prowadzić do naruszenia dóbr osobistych. Jeśli więc do sądu wpłynie wniosek złożony np. przez krewnego uczestnika postępowania, to sąd go oddali - nie badając jego merytorycznej zasadności. To jednak, że taki wniosek zostałby oddalony, nie oznacza, iż jeśli z analogicznym żądaniem wystąpi prokurator lub gminna komisja rozwiązywania problemów alkoholowych, to nie zostanie ono - w odrębnym postępowaniu - uwzględnione.

Istotne jest również, że podmioty uprawnione do złożenia wniosku powinny dysponować materiałem dowodowym, z którego co najmniej wynika, że uczestnik postępowania cierpi na chorobę alkoholową. Do wniosku dołącza się zebraną dokumentację wraz z opinią biegłego, jeżeli badanie przez biegłego zostało przeprowadzone. Warto przypomnieć uchwałę Sądu Najwyższego wydaną w dniu 11 września 2013 r., III CZP 52/13 (LEX nr 1371626), w której przyjęto, że niedołączenie do wniosku prokuratora o zastosowanie obowiązku leczenia odwykowego opinii biegłego albo wzmianki biegłego o okolicznościach uniemożliwiających jej wydanie stanowi brak formalny wniosku podlegający uzupełnieniu, pod rygorem zwrotu wniosku. Oznacza to, że już na etapie inicjowania postępowania sądowego podmiot uprawniony do złożenia wniosku powinien dysponować stosowną opinią ekspercką lub wzmianką biegłego o niemożliwości wydania opinii (Partyk, 2014, LEX/el).

Wydając postanowienie co do istoty sprawy, sąd, oprócz czynienia ustaleń co do tego, czy uczestnik jest osobą uzależnioną od alkoholu, powinien również 
ocenić, czy zgromadzony w sprawie materiał dowodowy pozwala na ustalenie, że zachodzi choćby jedna przesłanka społeczna spośród wymienionych w art. 24 ustawy. Jak podkreśla się w literaturze, każda z przesłanek społecznych może wystąpić niezależnie od innych. Zatem nie muszą one wystąpić łącznie (Horna-Cieślak, 2017, s. 16). Bez względu na powyższe spełnienie się przesłanki musi istnieć w powiązaniu z nadużywaniem przez uczestnika alkoholu, by móc uwzględnić złożony wniosek (Ignaczewski, 2014, s. 818).

W literaturze i orzecznictwie zwraca się uwagę, że w momencie orzekania konieczne jest istnienie obu przesłanek - medycznej i społecznej - łącznie. Jest to związane z tym, że „obie przesłanki w pewien sposób odzwierciedlają cele ustawy i funkcje tego środka, które są charakterystyczne dla postępowania nieprocesowego. Mowa tu o ochronie zarówno interesu indywidualnego, jak i społecznego (publicznego)" (Markiewicz, 2013, s. 406).

Jak podkreślił Sąd Najwyższy w postanowieniu z dnia 18 września 2015 r., I CSK 351/15 (LEX nr 1936709), sąd powinien badać spełnienie przesłanki społecznej (np. powodowania rozkładu pożycia) na dzień zakończenia rozprawy. Jeżeli została wniesiona apelacja, to znaczenie będzie miał stan istniejący w dacie zamknięcia rozprawy przed sądem odwoławczym, a nie w pierwszej instancji. W orzecznictwie podkreśla się bowiem, że sąd okręgowy, jako sąd odwoławczy, nie może pomijać wnioskowanych w postępowaniu apelacyjnym dowodów na okoliczność, czy spełnione są społeczne przesłanki zobowiązania uczestnika do podjęcia terapii odwykowej. Takie dowody mogłyby stawiać uczestnika w innym świetle i wpływać na ostateczny kształt rozstrzygnięcia, w szczególności gdyby jego zachowanie uległo poprawie lub pogorszeniu, ewentualnie również w przypadku podjęcia przez niego dobrowolnej decyzji o leczeniu odwykowym.

Dla oceny złożonego wniosku niezbędne jest zatem w szczególności dokonanie oceny, czy na przestrzeni prowadzonego postępowania zachowanie uczestnika ulega poprawie bądź pogorszeniu się. Jeśli uczestnik dopuszczał się zachowań godzących w dobro jego rodziny (np. nie pomagał w codziennych obowiązkach, wielokrotnie ubliżał bliskim, dopuszczał się rękoczynów itp.), a przez to prowadził do rozpadu rodziny, jednakże w toku postępowania następuje poprawa w jego zachowaniu, to konieczne jest zbadanie, czy nie jest to jedynie okresowa zmiana postawy, podjęta wyłącznie na potrzeby prowadzonego postępowania sądowego. Sąd Najwyższy w postanowieniu z dnia 10 stycznia 2018 r., I CSK 538/17 (LEX nr 2449300) zaznaczył, że sąd powinien dodatkowo ustalić, czy podjęta w toku postępowania przez uczestnika decyzja o podjęciu leczenia wynika z autentycznej chęci walki z nałogiem, czy też jest jedynie działaniem pozorowanym. Gołosłowne twierdzenia uczestnika o tym, że zmienił swoje zachowanie, nie mogą być wystarczające do uznania, że taka okoliczność ma miejsce. Rolą sądu jest więc zbadać, czy faktycznie jego najbliżsi zauważają zmianę zachowań uczestnika, gdyż „naturalnym jest, że krótkotrwałe zaprzestanie negatywnego zachowania alkoholika nie skutkuje ustaniem tego stanu, jeżeli oczywiście wcześniej nie nastąpił trwały rozkład" (Markiewicz, 2013, s. 406).

To na podmiocie uprawnionym do inicjowania postępowania spoczywa ciężar wykazania, że uczestnik postępowania powoduje rozkład życia rodzinnego (lub innej przesłanki społecznej z art. 24 ustawy). W procedurze cywilnej zastosowanie 
ma bowiem art. 6 k.c., zgodnie z którym ciężar udowodnienia faktu spoczywa na osobie, która z faktu tego wywodzi skutki prawne. Zatem to rolą wnioskodawcy jest złożyć wniosek, z którego wynikać będą okoliczności uzasadniające jego uwzględnienie (Horna-Cieślak, 2017, s. 12). W tym kontekście warto zwrócić uwagę na postanowienie Sądu Okręgowego w Białymstoku z dnia 27 czerwca 2014 r., II Ca 411/14 (LEX nr 1622621). Sąd ten podkreślił, że gdy uczestnik zaprzecza, aby spełnione były przesłanki ustawowe uzasadniające uwzględnienie wniosku, to wnioskodawca powinien przedstawić dowody. Natomiast bierność po stronie wnioskodawcy skutkować może oddaleniem wniosku. Z powyższego wynika, że wnioskodawca powinien dążyć do zgromadzenia stosownego materiału dowodowego, a wniosek powinien na materiał ten wskazywać, dzięki czemu możliwe będzie wykazanie jego zasadności. Odnośnie do analizowanej w niniejszym opracowaniu przesłanki społecznej wskazać należy, że dowodem na rozpad rodziny mogą być między innymi informacje o założeniu Niebieskiej Karty, dokumenty urzędowe, informacja o prowadzonych wobec uczestnika postępowaniach sądowych (zwłaszcza karnych), a także zeznania najbliższych uczestnika (np. współmałżonka, nieformalnego partnera, członków rodziny) lub osób obcych, które mają kontakty z uczestnikiem (np. sąsiadów, współpracowników). Istotne znaczenie ma niejednokrotnie to, czy uczestnik jest rozwiedziony (lub trwa proces o rozwód), a także czy sąd opiekuńczy prowadzi postępowania opiekuńcze w odniesieniu do małoletnich dzieci osoby uzależnionej od alkoholu (Sawuła, 2003, s. 291). Informacje zawarte w aktach innych postepowań mogą stanowić niemalże „kopalnię wiedzy” na temat sytuacji rodzinnej osoby uzależnionej. Dowodem w sprawie może być również wywiad środowiskowy (art. 30a ustawy).

\section{Pojęcie „powodowania rozkładu rodziny”}

Jak należy rozumieć przesłankę „powodowania rozkładu życia rodzinnego”? Na wstępie wskazać należy, że ustawodawca nie definiuje tego sformułowania, pozostawiając kwestię tę doktrynie i orzecznictwu.

Wątpliwości budzić może nawet to, względem kogo uzależniony od alkoholu uczestnik może prowadzić (bądź nie) do rozkładu życia rodzinnego. Ustawa nie zawiera bowiem definicji pojęcia „rodziny”. Przyjąć należy, że sformułowanie to powinno być rozumiane szeroko. W literaturze dotyczącej form wspólnego pożycia wskazuje się, że ,jako członka rodziny (lub osobę tworzącą inną formę wspólnego życia) uznać należy zatem osoby, które wspólnie ze sobą mieszkają i gospodarują, niezależnie od tego, czy są małżeństwem, niezależnie od pokrewieństwa i płci osób tworzących związek będący podstawą rodziny" (Krawiec, 2015, s. 220). Ma to o tyle znaczenie, że obecnie związki nieformalne są coraz bardziej powszechne i nie są już traktowane jako forma patologii (Partyk, 2018, s. 119-120). Oczywiście do kręgu tego należeć będą dzieci uczestnika, tak małoletnie, jak i dorosłe. Można przyjąć, że członkiem rodziny są również rodzice, rodzeństwo, dalsi krewni czy powinowaci uczestnika (np. jego pasierbowie) - okoliczność tą powinien sąd badać ad casum. 
W literaturze wskazuje się, że tę społeczną przesłankę należy rozumieć jako stan, w którym dochodzi do osłabienia więzi uczuciowych i gospodarczej (Sawuła, 2003, s. 286; Horna-Cieślak, 2017, s. 16). Gdy małżonkowie, dzieci, inne bliskie osoby zaczynają przestawać odczuwać wzajemną wspólnotę duchową, niewątpliwie można uznać, że istnieje już stan, którego utrwalenie może skutkować rozłamem rodziny, np. wystąpieniem z powództwem o rozwód czy ostatecznym rozejściem się nieformalnych partnerów. Badacze zwracają uwagę, że alkoholizm jednego z jej członków prowadzi niejednokrotnie do rozłamu tej komórki społecznej, zaś jednym z etapów go poprzedzających jest właśnie stan grożący rozbiciem rodziny - związany z dezorganizacją życia rodzinnego. Zanim on jednak nastąpi w życiu rodziny pojawia się system zaprzeczania problemowi, następnie chaos, lęk i paraliż emocjonalny (Zalas, 2011, s. 296). Co znamienne, zaburzony związek społeczny osoby uzależnionej z jego bliskimi nie jest zazwyczaj zauważany przez samą osobę nadużywającą alkoholu (Miśkowicz, 2013, s. 129).

Z punktu widzenia celów niniejszego opracowania warto przypomnieć pogląd wyrażony przez Sąd Najwyższy w postanowieniu z dnia 25 marca 2015 r., II CSK 828/14 (LEX nr 1677170). Zwrócił on uwagę, że przesłanka rozkładu życia rodzinnego jest podobna do przesłanki orzeczenia o rozwodzie małżonków, tj. rozkładu pożycia małżeńskiego. Jak wskazał SN:

różnice wynikają z oczywistego faktu, że na gruncie ustawy antyalkoholowej osobami, którym ustawa udziela ochrony, są wszyscy członkowie rodziny, ponadto sama rodzina traktowana jest szerzej, niż na gruncie kodeksu rodzinnego i opiekuńczego. [...] Przez rozkład życia rodzinnego należy zatem rozumieć sytuację, w której więzi łączące normalnie funkcjonującą rodzinę ulegają rozluźnieniu w stopniu utrudniającym jej spełnianie podstawowych funkcji.

Sąd Najwyższy w postanowieniu z dnia 13 kwietnia 2018 r., I CSK 763/17 (LEX nr 2533248) zwrócił uwagę, że stan powodowania rozkładu życia rodzinnego musi istnieć rzeczywiście (realnie), choćby tymczasowo. SN podkreślił w szczególności, że istnieją podstawy do uwzględnienia przez sąd złożonego wniosku, nawet jeśli następuje okresowa poprawa w zachowaniu uczestnika postępowania, w tym związana z prowadzonym postępowaniem sądowym. Pogląd ten jest aprobowany w literaturze. Gdyby bowiem przyjąć, że każda (choćby okresowa) pozytywna zmiana w postawie uczestnika wobec jego bliskich, mimo wcześniejszych ewidentnych zachowań godzących w dobro jego rodziny, uniemożliwia uwzględnienie wniosku, to przepisy ustawowe stałyby się w zupełności iluzoryczne (Markiewicz, 2013, s. 407).

Co do zasady rozkład pożycia rodzinnego nie następuje w wyniku jednorazowych zachowań uzależnionego od alkoholu członka rodziny, chyba że są one szczególnie drastyczne. Najczęściej proces ten jest rozciągnięty w czasie. Zwrócić uwagę należy, że rozkład pożycia rodzinnego może wynikać z tego, że osoba uzależniona od alkoholu, która zaniedbuje swoje obowiązki wobec bliskich, często jest wyręczana przez innych krewnych lub współmałżonka, co negatywnie odbija się na relacjach rodzinnych. Często małżonek osoby uzależnionej „bierze na siebie” część zadań, które zaniedbuje uzależniony, a tym samym uczy go, iż jest to stan akceptowalny (Szczepańska, 1994, s. 44-45, 
$54,59)$. Stan beznadziei w rodzinie alkoholowej często oznacza „głębokie uwikłanie w patologię alkoholową małżonka lub rodzica” (Mellibruda, 2001, s. 44). W literaturze wskazuje się też, że nadużywanie alkoholu przez męża jest niejednokrotnie czynnikiem zwiększającym ryzyko zgwałcenia małżonki (Krajewski, 2009, s. 245-247).

Sąd Najwyższy w postanowieniu z dnia 9 grudnia 1998 r., II CKN 948/98 (LEX nr 1214500) uznał, że bez względu na to, iż żona uczestnika cofnęła pozew o rozwód i wyjechała z nim na wakacje, istniały podstawy do uznania, że dochodzi do rozkładu pożycia małżonków, choć stan ten nie miał cechy trwałości. SN wskazał, że zewnętrznym wyrazem kryzysu w rodzinnego uczestnika były nieporozumienia małżeńskie. Z ustaleń wynikało bowiem, że wcześniej uczestnik, pod wpływem alkoholu, używał wobec swojej żony słów powszechnie uznawanych za obelżywe i rzucał w nią ubraniami.

Natomiast Sąd Okręgowy w Kielcach w postanowieniu z dnia 25 kwietnia 2014 r., II Ca 564/14 (LEX nr 1622758) zobowiązał uczestnika do podjęcia leczenia w niestacjonarnym zakładzie lecznictwa odwykowego. Sąd odwoławczy nie zgodził się z sądem rejonowym, który ocenił, że choć uczestnik powoduje awantury domowe i jest w konflikcie z żoną, nie powoduje rozpadu swojej rodziny. Sąd odwoławczy dobitnie podkreślił jednak, uwzględniając apelację prokuratora, że uczestnik przez swój nałóg alkoholowy powoduje rozkład życia rodzinnego i demoralizuje małoletnich. Sąd drugiej instancji zwrócił uwagę, że żona uczestnika musi pilnować odbioru jego renty (jedynego źródła utrzymania małżonków) i chowa przed nim ostre przedmioty, jeśli znajduje się on pod wpływem alkoholu. Małoletnie wnuki uczestnika boją się go, gdy jest pijany. Sąd przyjął, że takie okoliczności wskazują na powodowanie przez uczestnika rozkładu pożycia rodzinnego.

Z kolei Sąd Okręgowy w Słupsku w postanowieniu z dnia 18 lutego 2014 r., IV Ca 29/14 (LEX nr 1883857) wskazał, że uzależniona od alkoholu uczestniczka powodowała rozpad więzi rodzinnych. Z zeznań świadków wynikało bowiem, że uczestniczka pod wpływem alkoholu ubliża swoim bliskim, staje się agresywna. Gdy jej córka była w ciąży, pijana uczestniczka groziła zepchnięciem jej ze schodów. Sądy ustaliły też, że zachowania uczestniczki źle oddziałują na jej dorosłego i niepełnosprawnego syna, który sam staje się agresywny.

Natomiast z ustaleń Sądu Rejonowego w Krośnie leżących u podstaw postanowienia z dnia 16 stycznia 2017 r., III RNs 283/16 (LEX nr 2344261) wynikało, że żona uczestnika starała się unikać nietrzeźwego małżonka z obawy przed nieprzyjemnymi sytuacjami i jego agresją. Żona uczestnika niejednokrotnie pozbawiana była też snu przez męża, gdy znajdował się pod wpływem alkoholu lub gdy trzeźwiał. Sąd pierwszej instancji dostrzegł, że małżonkowie oddalili się od siebie, co wskazywało na stan rozkładu życia w rodzinie uczestnika.

Warto także zwrócić uwagę na stan faktyczny ustalony przez Sąd Rejonowy w Wieliczce, IV RNs 134/17 (LEX nr 2317807). W postanowieniu z dnia 9 czerwca 2017 r. sąd orzekł o zobowiązaniu uczestnika do poddania się leczeniu odwykowemu w systemie stacjonarnym. Z opinii biegłych wynikało, że uczestnik jest osobą uzależnioną od alkoholu. Sąd przyjął też, że uczestnik powoduje rozkład więzi rodzinnych. Uczestnik potwierdził zresztą przed sądem, że pozostaje w wieloletnim konflikcie ze swoją siostrą i dochodzi 
do awantur, podczas których interweniuje policja. Jak wskazał sąd, „co prawda uczestnik wyklucza, aby konflikt ten pozostawał w związku z nadużywaniem alkoholu, starając się powiązać go z tocząca się sprawą o dział spadku, jednakże argumentacja ta nie zasługuje na uwzględnienie".

\section{Przyczyny nieuwzględniania wniosków przez sądy}

Wśród powodów, dla których sądy odmawiają uwzględnienia wniosków o zobowiązanie osoby uzależnionej od alkoholu do podjęcia leczenia odwykowego, zwrócić należy uwagę - w kontekście przesłanki w postaci powodowania rozkładu pożycia rodziny - na dwa najbardziej doniosłe. Pierwszy z nich to brak rzeczywistego występowania tej przesłanki. Drugi zaś to dokonanie się w dacie zakończenia postępowania sądowego definitywnego rozkładu pożycia.

Jak już wskazałam, jeśli z analizy materiału zgormadzonego w sprawie nie wynika, by zachowania uczestnika prowadziły do rozkładu pożycia rodziny (a brak innych przesłanek społecznych), to mimo że cierpi on na uzależnienie alkoholowe, wniosek o zobowiązanie go do przymusowego leczenia odwykowego nie może być uwzględniony. Takie zapatrywanie wyraził w szczególności Sąd Okręgowy w Rzeszowie w postanowieniu z dnia 24 stycznia 2014 r., V Ca 163/14 (LEX nr 1622293). Sąd ten zmienił postanowienie sądu rejonowego, którym zobowiązano uczestnika do podjęcia leczenia w trybie niestacjonarnym, i oddalił wniosek. Sąd odwoławczy, analizując materiał dowodowy, podkreślił, że nie można zgodzić się z sądem rejonowym, że uczestnik powoduje rozkład życia rodzinnego. Wykluczono bowiem, aby uczestnik stosował przemoc w rodzinie. Z akt sprawy nie wynikało również, by uczestnik zaniedbywał swoich najbliższych lub odmawiał im pomocy. Sąd okręgowy podkreślił, że ustalenie tego, czy uczestnik powoduje rozkład życia rodzinnego, nie może być czynione na podstawie dowodu z opinii biegłych sądowych z zakresu psychiatrii i psychologii, jak błędnie przyjął to sąd pierwszej instancji. Sąd odwoławczy zaznaczył, że z rzeczonej opinii wynikało jedynie to, że uczestnik cierpi na uzależnienie alkoholowe i bagatelizuje swój nałóg.

Jednocześnie nie można każdego konfliktu w rodzinie uczestnika kwalifikować jako tożsamego z powodowaniem rozkładu życia rodzinnego. Interesujące rozważania w tym przedmiocie zaprezentował Sąd Okręgowy w Świdnicy w postanowieniu z dnia 11 marca 2014 r., II Ca 967/13 (LEX nr 1622464). Sąd ten zmienił zaskarżone orzeczenie i orzekł o oddaleniu wniosku, przyjmując, że nie zostało wykazane, że uczestnik powoduje rozkład życia rodzinnego. Sąd zaznaczył, że małżonkowie byli skonfliktowani z uwagi na nadużywanie przez uczestnika alkoholu, ale z materiału dowodowego nie wynikało w sposób ewidentny, by ten stan prowadził do rozkładu życia rodzinnego. Sam fakt występowania napięć pomiędzy uczestnikiem a jego żoną nie uzasadniał przyjęcia, że spełniona została przesłanka społeczna leczenia odwykowego przeciwalkoholowego, a zarazem uczestnik z własnej inicjatywy podejmował próby leczenia dobrowolnego i kontaktował się z psychoterapeutą, co w ocenie sądu rokowało lepiej aniżeli leczenie „przymusowe”. 
Również Sąd Rejonowy w Wołowie w postanowieniu z dnia 16 listopada 2017 r., III RNs 96/17 (LEX nr 2420963) oddalił złożony wniosek o zobowiązanie uczestnika do podjęcia leczenia odwykowego. Z ustaleń sądu wynikało, że uczestnik cierpi na uzależnienie alkoholowe, natomiast w toku postępowania jego zachowanie uległo poprawie. Sąd podkreślił w szczególności, że nie można uznać, aby na dzień orzekania przesłanka powodowania rozkładu życia rodzinnego istniała, skoro m.in. pomagał on bliskim w pracach domowych. Sąd zauważył, że na poprawę relacji w rodzinie uczestnika najlepiej wskazuje to, iż matka uczestnika domagała się umorzenia postepowania, choć to ona podejmowała wcześniej starania o jego zainicjowanie.

Analogiczne rozstrzygnięcia sądów - oddalające złożony wniosek - zapadają, jeśli z ustaleń sądu wynika, że rozpad rodziny uczestnika nie istnieje, gdyż nie pozostaje on w związku małżeńskim lub konkubinacie, mieszka sam i nie ma na utrzymaniu dzieci. Takie stanowisko wyraził w szczególności Sąd Rejonowy w Wieliczce w postanowieniu z dnia 22 września 2017 r., IV RNs 211/17 (LEX $\mathrm{nr}$ 2363671). Z ustaleń sądu wynikało, że uczestnik jest osobą uzależnioną od alkoholu. Sąd oddalił wniosek, bowiem wnioskodawca nie wykazał, aby zaistniała choć jedna z przesłanek społecznych wymienionych w ustawie o wychowaniu w trzeźwości i przeciwdziałaniu alkoholizmowi. Sąd ten podkreślił, że ze znajdującej się w aktach informacji od sołtysa wynikało, że uczestnik cieszy się dobrą opinią w lokalnej społeczności, nie jest widywany pod wpływem alkoholu i płaci podatki.

Z kolei Sąd Okręgowy Warszawa-Praga w Warszawie w postanowieniu z dnia 6 maja 2014 r., IV Ca 89/14 (LEX nr 1883650) uznał brak podstaw do zakwalifikowania zachowań uczestnika nadużywającego alkoholu jako prowadzących do rozkładu pożycia rodzinnego. Sąd podkreślił, że uczestnik przed wszczęciem postępowania rozstał się z nieformalną partnerką. Zamieszkał on z rodzicami, z którymi jest skonfliktowany, ale spór w rodzinie nie wynika z jego uzależnienia, lecz motywowany jest kwestiami finansowymi. Sąd okręgowy zwrócił także uwagę, że uczestnik ma kontakt ze swoim dzieckiem, którym opiekuje się raz lub dwa razy w tygodniu. Na podstawie akt postepowania nie można było uznać, że matka dziecka utrudniała te spotkania z uwagi na uzależnienie uczestnika.

W judykaturze przyjmuje się jednak również, że jeśli wniosek o zobowiązanie osoby uzależnionej od alkoholu został złożony już po definitywnym rozkładzie życia rodzinnego (a więc gdy już doszło do tego skutku) lub gdy rozpad więzi rodzinnych nastąpił w toku postępowania sądowego, to brak jest podstaw do uwzględnienia złożonego wniosku o zobowiązanie uczestnika do podjęcia leczenia odwykowego. W orzecznictwie zwraca się bowiem uwagę, że przepisy o obowiązku leczenia uzależnienia alkoholowego muszą być interpretowane w sposób wąski, a więc restrykcyjny. Takie zapatrywanie przedstawił w szczególności Sąd Najwyższy w postanowieniu z dnia 9 listopada 2007 r., V CSK 241/07 (LEX nr 361289).

Podobnie Sąd Okręgowy w Nowym Sączu w sprawie III Ca 642/13 (LEX nr 1622939) w postanowieniu z dnia 23 października 2013 r. wskazał, że „uzależnienie uczestnika od alkoholu spowodowało już rozkład życia rodzinnego i rozluźnienie więzi łączących normalnie funkcjonującą rodzinę w stopniu 
utrudniającym jej spełnianie podstawowych funkcji”. W związku z powyższym sąd odwoławczy zmienił wydane przez sąd rejonowy postanowienie i oddalił wniosek. Nastąpił już bowiem trwały rozłam w rodzinie uczestnika. Jego żona, składając pozew o rozwód, podnosiła, że jej i męża nie łączą już więzi fizyczne, duchowe i gospodarcze. Ponadto z ustaleń sądu wynikało, że uczestnik miał dorosłych synów, którzy z nim nie mieszkali. Sąd odwoławczy, zmieniając zaskarżone przez uczestnika orzeczenie sądu pierwszej instancji, podkreślił, że wystąpienie samej tylko przesłanki medycznej nie jest wystarczające dla uwzględnienia wniosku.

Również Sąd Okręgowy w Słupsku w postanowieniu z dnia 15 marca 2013 r., IV Ca 83/13 (LEX nr 1622386) stwierdził brak podstaw do zobowiązania uczestniczki do podjęcia leczenia przeciwalkoholowego, bowiem z ustaleń wynikało, że rozkład życia jej rodzinnego nastąpił już wiele lat przed prowadzeniem postępowania sądowego. Sąd zwrócił uwagę, że uczestniczka jest rozwódką i mieszka sama. Zanim nie zostało wszczęte postępowanie sądowe zdarzało się, że uczestniczka nękała telefonami swojego dorosłego i samodzielnego syna, ale sytuacji tej nie można było określić jako powodującej rozkład życia rodzinnego. Biorąc pod uwagę powyższe, sąd odwoławczy zmienił zaskarżone postanowienie i oddalił wniosek.

\section{Podsumowanie}

Przedstawiony wybór orzeczeń sądowych unaocznia, że w przypadku, gdy konflikty wynikające z nadużywania alkoholu stają się normą w życiu rodziny, to zachodzi przesłanka społeczna - powodowanie rozkładu życia rodzinnego, co w powiązaniu z zaistnieniem przesłanki medycznej może skutkować uwzględnieniem wniosku o zobowiązanie uczestnika do podjęcia leczenia odwykowego. Jednak sąd bada zasadność wniosku według stanu na moment zakończenia rozprawy. Gdy zatem w tym czasie życie rodziny uczestnika legło już w gruzach, to nie ma podstaw do przyjmowania, że omawiana przesłanka ustawowa jest spełniona.

Kryzys rodziny, której rozłam związany jest z alkoholizmem jednego z jej członków, wymaga ustanowienia przez państwo odpowiednich rozwiązań prawnych. W literaturze wskazuje się, że dziecko rosnące w domu, w którym alkohol zajmuje pierwszoplanową rolę, ma poważnie utrudniony rozwój, co negatywnie wpływać będzie na jego osobowość (Głuszek-Osuch, 2006, s. 85). Tam, gdzie nadużywanie alkoholu łączy się z przemocą lub niedopełnianiem obowiązków rodzinnych, następuje - czasem powolny, czasem szybki - proces, który zakończyć może się całkowitym rozbiciem rodziny, bądź życiem pod jednym dachem osób sobie bliskich tylko w teorii. Analiza orzecznictwa wskazuje, że kwestia tego, czy dane nieprawidłowe zachowania osoby uzależnionej można zakwalifikować już jako prowadzące do rozkładu pożycia w rodzinie jest ocenna. Pojęcie „powodowania rozkładu życia rodzinnego" jest bowiem nieostre. To od dyskrecjonalnej decyzji sądu zależeć będzie zatem, czy uczestnik zostanie zobowiązany do poddania się leczeniu odwykowemu czy też nie. W tym miejscu warto jednak 
przypomnieć, że „alkoholizm jest chorobą całej rodziny, a nie tylko osoby pijącej, czyniąc ją jednocześnie rodziną dysfunkcjonalną, a więc taką, która nie funkcjonuje w sposób prawidłowy" (Zalas, 2011, s. 287). Stąd tak ważne jest, aby w przypadku, gdy uzależnienie alkoholowe coraz bardziej wpływa na los jego rodziny, uczestnik zostawał jednak zobowiązany sądownie do odbycia terapii odwykowej. Pewna część osób uzależnionych przechodzi z sukcesem terapię odwykową. Dokąd ustawodawca nie zmieni uregulowań prawnych, sądy powinny zobowiązywać do odbywania terapii odwykowej te osoby, których zachowanie wymaga napiętnowania, zanim dojdzie do ostatecznego rozłamu rodziny. Im szybciej i wcześniej takie postępowania będą inicjowane, tym większa szansa na poprawę sytuacji samego uzależnionego i jego najbliższych. Dobro krzywdzonych przez osobę nadużywającą alkoholu wymaga reakcji ze strony aparatu państwowego, choć w obecnym stanie prawnym nie można mówić o systemie przymusowego leczenia, a tylko o „przymuszaniu” do podjęcia terapii. Z uwagi na realizowane cele ustawy o wychowaniu w trzeźwości i przeciwdziałaniu alkoholizmowi dochodzić może do ograniczeń określonych swobód (Krawiec, 2008, s. 78-79). Wolność osób zainteresowanych nadmiernym i szkodliwym spożywaniem alkoholu nie może być jednak traktowana jako nieograniczona. Dobro rodziny, szczególnie małoletnich dzieci, wymaga podejmowania szybkich i zdecydowanych działań, które być może nie we wszystkich przypadkach - ale jednak - odniosą pozytywne efekty.

\section{Bibliografia}

Fiutak A. (2016), Odpowiedzialność karna za wykonanie zabiegu leczniczego bez zgody pacjenta, Wolters Kluwer, Warszawa.

Głuszek-Osuch M. (2006), Spostrzeganie więzi rodzinnych przez dzieci pochodzące z rodzin alkoholowych, „Studia Medyczne Akademii Świętokrzyskiej” 3, s. 79-100.

Grotkowska K. (2018), Uzależnienia. Wokół pojęć „używanie” i „nadużywanie”, „Przegląd Prawa Publicznego" 7-8, s. 84-92.

Horna-Cieślak M. (2017), Orzekanie oraz wykonywanie obowiązku leczenia odwykowego z ustawy o wychowaniu w trzeźwości i przeciwdziałaniu alkoholizmowi, Instytut Wymiaru Sprawiedliwości, Warszawa.

Ignaczewski J. (2014), Komentarz do spraw o leczenie odwykowe alkoholików, [w:] H. Ciepła, J. Ignaczewski, J. Skibińska-Adamowicz (red.), Komentarz do spraw rodzinnych, LexisNexis, Warszawa, s. 736-737.

Krajewski R. (2009), Prawa i obowiązki seksualne małżonków. Studium prawne nad normą i patologią zachowań, Oficyna a Wolters Kluwer business, Warszawa.

Krawiec G. (2008), Zgoda właściciela, użytkownika, zarządcy lub administratora budynku mieszkalnego wielorodzinnego jako warunek uzyskania zezwolenia na sprzedaż napojów alkoholowych, „Finanse Komunalne” 5, s. 72-79.

Krawiec G. (2015), Koncepcje płci człowieka a prawo administracyjne, Biuro RPO, Warszawa.

Markiewicz K. (2013), Moment właściwy dla oceny występowania przesłanek do orzeczenia o obowiązkowym leczeniu w zakładzie lecznictwa odwykowego, „Polski Proces Cywilny” 3, s. 297-300.

Mellibruda J. (2001), Alkohol i życie codzienne, Lerovil, Otwock.

Miśkowicz M. (2013), Problemy współczesnej rodziny w dobie promowania wartości prorodzinnych, „Pedagogika Rodziny” 3(1), s. 111-128.

Partyk A. (2014), Czasem przymus nie zastąpi dobrej woli uczestnika postępowania, „Prawnik” 167, s. C2. 
Partyk A. (2014), Wymogi formalne wniosku o leczenie odwykowe przeciwalkoholowe. Glosa do uchwały SN z dnia 11 września 2013 r., III CZP 52/13. Internetowy system Informacji Prawnej LEX, Wolters Kluwer.

Partyk A (2018), Uprawnienia konkubenta spadkodawcy w prawie szkockim, „Kwartalnik Prawa Prywatnego" 1 , s. 119-146.

Sawuła R. (2003), Wychowanie w trzeźwości i przeciwdziałanie alkoholizmowi. Tekst ustawy z komentarzem, orzecznictwem i aktami wykonawczymi, Wyższa Szkoła Administracji i Zarządzania w Przemyślu, Rzeszów.

Szczepańska H. (1994), Żony alkoholików, Instytut Psychologii Zdrowia i Trzeźwości, Warszawa.

Zalas K. (2011), Rodzina z problem alkoholowym, „Prace naukowe AJD. Pedagogika” 20, s. 285-303.

\section{Abstract}

The provisions of the Act of 26 October 1982 on Upbringing in Sobriety and Counteracting Alcoholism provide for the possibility of applying obligatory withdrawal treatment to an addicted person. Compulsory withdrawal treatment may be provided in a stationary or inpatient system. However, both forms of addiction treatment constitute a statutory exception, as withdrawal treatment is voluntary in principle. In particular, judicature points out that alcohol dependence alone is not sufficient to oblige a participant to undertake alcohol treatment. There must also be a so-called social premise. One such premise is the fact that an addicted person is causing a breakdown of family life. In the jurisprudence of courts this circumstance is often referred to. However, whether this actually takes place is a matter of judgement. Not every conflict within a family constitutes a breakdown of family life. Moreover, the application cannot be taken into account if the family ties have already definitively disintegrated. At the same time, the court takes into account the state existing at the date of closing of the hearing, and therefore the improvement of the addicted person's conduct, including the initiation of voluntary therapy, must influence the final direction of the court's decision. A decision on the obligation to undertake alcohol treatment is particularly important if there is real fear that a crisis in a family affected by alcoholism of one of its members will deepen. Rapid reaction on the part of the state apparatus increases the probability of success.

Keywords: family, dependence, alcoholism, withdrawal treatment 